DOI: $10.33242 /$ rbdc.2021.02.008

\title{
ALGUMAS CONSIDERAÇÕES SOBRE A REFORMA DO DIREITO DOS CONTRATOS ${ }^{1}$
}

\section{QUELQUES MOTS SUR LA RÉFORME DE LA RÉFORME DU DROIT DES CONTRATS}

\author{
Denis Mazeaud \\ Professor da Universidade Panthéon-Assas (Paris 2). \\ Victor Willcox (Tradutor) \\ Mestre e Doutorando em Direito Civil pela Universidade do Estado do \\ Rio de Janeiro - UERJ. Procurador do Município do Rio de Janeiro. Advogado.
}

Resumo: Mal fora aprovada a reforma do direito dos contratos, da prova e das obrigações (objeto do decreto-lei de 10.2.2016), o legislador votou, imediatamente depois, no último 11 de abril, uma lei de ratificação. Certamente, o novo texto não alterou substancialmente o precedente. Sob o aspecto quantitativo, as modificações não foram numerosas. Mesmo assim, a lei de ratificação trouxe alterações. Algumas aceitáveis, outras lamentáveis.

Palavras-chave: Contrato. Obrigações. Reforma. Lei de ratificação. Comentário.

Sumário: I Dores (de cabeça...) - II 0 necessário, provavelmente - III 0 excessivo (poderíamos ter ficado sem...) - IV O reconfortante (para os admiradores do modelo contratual tradicional francês) - $\mathbf{V} O$ menos bom... - VI O melhor

1 Apenas “algumas considerações", porque, para se ter uma visão completa sobre a Lei no 2018-287 de 20.4.2018 de ratificação do decreto-lei de 10.2.2016, publicado no Diário Oficial do último 21 de abril, basta se reportar ao comentário exaustivo e minucioso do nosso colega Mustapha Mekki, publicado nesta mesma Coleção. $^{2}$

1 Texto traduzido por Victor Willcox, no âmbito do curso de Doutorado em Direito Civil do Programa de PósGraduação da Faculdade de Direito da Universidade do Estado do Rio de Janeiro - UERJ.

2 M. Mekki, La loi de ratification de l'ordonnance du 10 février 2016. Une réforme de la réforme?, ce numéro, p. 900; D. Houtcieff, Loi de ratification de l'ordonnance de réforme du droit des contrats de la preuve et du régime des obligations: le droit schizophrène, Gaz. Pal. 7 avr. 2018, p. 14. 
2 "Reforma da reforma", porque é exatamente isto que traz a lei de ratificação. Contudo, era concebível, talvez até mesmo preferível no interesse dos artesãos do direito dos contratos (advogados, juristas, magistrados), optar por "uma ratificação enxuta do decreto-lei de 10/02/2016 deflagrando a reforma do direito dos contratos". 3 Isso teria evidentemente suposto que, a despeito de algumas aproximações, imperfeições, contradições e lacunas do decreto-lei, ter-se-ia confiado no juiz para corrigilas, resolvê-las ou colmatálas. Para aqueles que, como o autor destas linhas, estão convencidos de que os juízes serão os coautores da reforma, tal posição era não apenas viável, mas ainda desejável. Isso teria evitado, de todo modo, fortes dores de cabeça a todos aqueles que deverão colocar a reforma em prática, deparando-se doravante com três regimes jurídicos aplicáveis, ao invés de dois...

Certamente a lei de ratificação não desfigurou o decreto-lei de 2016. Não houve o retorno da causa, não se abandonou a revisão judicial por imprevisão, ainda que o abandono de uma e a admissão de outra sejam essencialmente simbólicos, porquanto as funções da causa foram mantidas e a ingerência do juiz pode vir a ser afastada por uma cláusula em sentido contrário.

Certamente, a lei de ratificação não resolve todas as questões suscitadas pela doutrina ao dissecar as disposições do decreto-lei, e é melhor que assim seja. Caberá à Corte de Cassação decidir, nos próximos anos, se o art. 1.163 do Código Civil tem como objeto o preço, tal como sugerem os artigos subsequentes. Caberá a ela também decidir se o art. 1.165 revoga a jurisprudência ancestral que permitia ao juiz revisar os honorários excessivos dos mandatários e dos empreiteiros! A ela também caberá pronunciar-se sobre a validade de uma cláusula pela qual o credor possa deflagrar a execução forçada contra o devedor de boa-fé, mesmo em caso de desproporção manifesta entre o interesse que esta sanção estabelece para ele e o custo que ela representa para a sua contraparte. E daí em diante, pois, sem dúvidas, as questões a serem enfrentadas pela Corte não param por aí. Sob essa perspectiva, ela poderá inspirar-se - é permitido sonhar - na literatura abundante com relação a tais questões, ${ }^{4}$ tendo em mente que, se os juízes serão os coautores da reforma, os próprios autores (ao menos alguns deles) desempenharam um papel fundamental na sua concepção, tanto inicial quanto final.

Certamente... Mas a lei de ratificação merece, apesar disso, ser recebida como uma genuína reforma da reforma, motivo pelo qual não se endossa a opinião do nosso querido Mustapha Mekki, o qual sustenta que a nova legislação

N. Molfessis, JCP 2017. 1045.

4 G. Chantepie et M. Latina, La réforme du droit des obligations, Dalloz, 2016; F. Chénedé, Le nouveau droit des obligations et des contrats, Dalloz, 2016; O. Deshayes, T. Genicon et Y.-M. Laithier, Réforme du droit des contrats, du régime général et de la preuve des obligations, LexisNexis, 2016; N. Dissaux et C. Jamin, Réforme du droit des contrats, du régime général et de la preuve des obligations, Dalloz, 2016. 
"se contentou, na linha das intenções originais, em consolidar o essencial". ${ }^{5} \mathrm{~A}$ afirmação é indiscutível sob o plano quantitativo, mas não convence ao menos do ponto de vista qualitativo. Com efeito, o legislador modificou substancialmente algumas disposições emblemáticas do decreto-lei - notadamente, mas não exclusivamente, aquela que implicava uma verdadeira revolução do nosso modelo contratual ao integrar o contrato de adesão no Código Civil.

3 Sem qualquer pretensão de exaustividade, debruçar-nos-emos sobre algumas disposições da lei de ratificação que, em maior ou menor extensão, culminaram em uma reforma do decreto-lei de 10.2.2016 no âmbito do direito dos contratos.

\section{| Dores (de cabeça...)}

4 Mencionaremos brevemente, neste estágio, a questão do conflito de leis no tempo, ${ }^{6}$ podendo-se dizer que, da forma como está, três regimes de direito contratual coexistem: o direito anterior ao decreto-lei para os contratos em curso, celebrados antes da sua entrada em vigor (1‥10.2016); o direito objeto do decreto-lei para os contratos celebrados após a sua entrada em vigor; e o direito concebido pela lei de ratificação para aqueles celebrados após a entrada desta em vigor (1ํ.10.2018). Não invejamos nem um pouco os profissionais do direito, que deverão ser extremamente vigilantes, devido a essa pluralidade de leis potencialmente aplicáveis aos contratos que eles terão em suas mãos.

5 A fim de evitar que os juízes apliquem as disposições do decreto-lei aos contratos em curso, a lei de ratificação dispõe que os contratos celebrados antes da sua entrada em vigor serão regidos pela lei anterior, "compreendidos como tais com relação aos seus efeitos legais e às disposições de ordem pública”. Há o risco de que esse dispositivo esteja apenas enxugando gelo, uma vez que a arma aparentemente fatal utilizada pelos magistrados, notadamente pela Corte de cassação, para aplicarem as disposições do decreto-lei aos contratos em curso é mais sofisticada. Essa arma consiste em resolver um litígio contratual relativo a contratos dessa natureza, elucidando-se o caso à luz das novas disposições do decreto-lei. ${ }^{7}$ A lei de ratificação, contudo, não neutraliza esse poder. Se formos

\footnotetext{
Eod. loc., no 38 .

Sobre esse ponto, V. M. Mekki, eod. loc., spéc. no $8 \mathrm{~s}$.

Nesse sentido, Cass., ch. mixte, 24/02/2017, no 15-20.411, D. 2017. 793, note B. Fauvarque- Cosson, 1149, obs. N. Damas, et 2018. 371, obs. M. Mekki; AJDI 2017. 612, obs. M. Thioye, et 2018. 11, étude H. Jégou et J. Quiroga-Galdo; AJ Contrat 2017. 175, obs. D. Houtcieff; RTD civ. 2017. 377, obs. H. Barbier; JCP 2017, no 305, note B. Sturlèse; Civ. 1re, 20/09/2017, no 16-12.906, D. 2017. 1911; RTD civ. 2017. 837, obs. H. Barbier; Soc. 21/09/2017, № 16-20.103 et 16-20.104, D. 2017. 2007, note D. Mazeaud, 2289, note B. Bauduin et J. Dubarry, 2018. 371, obs. M. Mekki, et 435, obs. S. Karaa; AJ Contrat 2017.
} 
refratários a este poder outorgado ao juiz de aplicar uma lei nova aos contratos em curso, precisaremos nos preocupar? Sem dúvidas, não muito. Primeiro, porque os dois primeiros julgados citados representavam apenas uma exceção ao princípio da sobrevivência da lei antiga em matéria contratual, uma vez que, quanto à questão decidida pela Corte à luz das disposições do decreto-lei, este codificava pura e simplesmente o direito anterior. Em seguida, porque, nos julgados proferidos pela câmara social, certamente, esta modificava, em sua fundamentação, o direito anterior ao voltar atrás em relação à sua jurisprudência acerca da sanção da revogação de uma promessa unilateral de contrato. No entanto, essa modificação era inócua, porquanto a Corte mantivera a qualificação da oferta referente ao ato sobre cuja ruptura ela devia decidir. Por fim, como assinalou Laurent Leveneur, ${ }^{8}$ “aqui, na verdade, não havia anteriormente 'lei antiga' precisa sobre o assunto (as coisas teriam sido diferentes se um texto claro existisse: seria necessário aplicá-lo)". Há, pois, tantas razões para não se alarmar demasiadamente com o silêncio da lei de ratificação sobre esse ponto específico.

6 Para temperar os efeitos nefastos da sobreposição de regimes jurídicos potencialmente aplicáveis aos contratos em curso, a lei de ratificação dispõe também que alguns textos modificativos têm um caráter interpretativo e, como tais, aplicar-se-ão aos contratos celebrados após a entrada em vigor do decreto-lei. Em termos de segurança jurídica, o propósito é louvável, mas não estamos menos certos de que, entre tais textos pretensamente interpretativos, o novo art. 1.143, por exemplo, "se limita a reconhecer, sem nada inovar, um direito preexistente que uma definição imperfeita tornou suscetível de controvérsias". ${ }^{9} \mathrm{E}$, em sendo este o caso, um controle da retroatividade desse texto poderia então ser exercido, tal como iniciado pelo Conselho Constitucional e intensificado pela Corte Europeia de Direitos Humanos. ${ }^{10}$

\section{0 necessário, provavelmente}

7 Serão simplesmente evocadas, aqui, as correções que se fazem manifestamente impositivas em matéria de capacidade (art. 1.145, al. 2) e de representação (art. 1.161). Esses textos contêm falhas, talvez porque os redatores não

480, obs. C.-E. Bucher; Dr. soc. 2018. 170, étude R. Vatinet, et 175, étude Y. Pagnerre; RDT 2017. 715, obs. L. Bento de Carvalho; RTD civ. 2017. 837, obs. H. Barbier; CCC 2017. Comm. 238, obs. L. Leveneur; Gaz. Pal. 2017. 2662, note M. Latina; JCP 2017. 1238, obs. N. Molfessis.

8 Obs. préc.

9 Soc. 3.10.1957, Bull. civ. IV, no 899; no mesmo sentido, M. Mekki, eod. loc., spéc. no 13.

10 Sobre esse ponto, v., entre outros, P. Deumier, Introduction générale au droit, LGDJ, 2017, ํo 286. 
tenham levado em consideração os efeitos colaterais de uma reforma do direito comum dos contratos sobre o direito especial, notadamente o direito das sociedades. Especialistas na área, bem como, sem dúvidas, forças mais obscuras, mas não menos influentes, levantaram suas vozes e foram ouvidos pelos parlamentares, ao que tudo indica.

8 Como a cessão de contrato e a cessão de crédito, a cessão de dívida, inovação relativa do decreto-lei, torna-se um contrato solene. A ratio legis não é mais evidente para esta cessão do que para aquelas outras, mas, de todo modo, o nosso direito ganha coerência, o que é melhor que nada...

9 A reparação do prejuízo em caso de ruptura desleal de uma negociação contratual não podia, sob o império do decreto-lei, "ter por objeto compensar a perda das vantagens esperadas do contrato não concluído" (art. 1.112, al. 2). Essa regra constituía uma codificação da jurisprudência inaugurada por um julgado proferido em 26.11.2003 pela câmara comercial da Corte de Cassação, ${ }^{11}$ com a ressalva de que a regra legal não era a réplica exata da regra jurisprudencial. No julgado anteriormente citado, com efeito, a Corte havia decidido que o prejuízo reparável não poderia consistir nem no equivalente à perda da vantagem esperada com a celebração do contrato cuja negociação fora rompida de forma desleal, nem na perda da chance de obter uma tal vantagem. O decreto-lei, por descuido de seus autores, silenciara sobre esse segundo tipo de prejuízo. Não teria sido arriscado deixar para a Corte de cassação o cuidado de remediar esse esquecimento. Mas a lei de ratificação completa o decreto-lei sobre esse ponto e codifica em sua integralidade a referida regra jurisprudencial.

Na mesma ordem de ideias, pode ser considerada a reforma do art. 1.165, com relação à nova sanção em caso de fixação unilateral de um preço abusivo em matéria de contratos de prestação de serviços: além da pretensão indenizatória, o devedor do preço pode, "conforme o caso, [postular] a resolução do contrato". Mais uma vez, não é proibido pensar que a Corte de Cassação não tinha necessidade desse salvo-conduto do legislador para pronunciar uma tal sanção, mas, como o art. 1.164 prevê essas duas sanções para o preço abusivo fixado unilateralmente em um contrato de fornecimento, uma preocupação de simetria (se não de mera elegância) pode justificar essa modificação.

11 A.-S. Dupré-Allemagne, D. 2004. 869; JCP 2004. I. 163, № 18, obs. G. Viney; JCP E 2004. 738, obs. P. Stoffel-Munck; RDC 2004. 257, obs. D. Mazeaud; RTD civ. 2004. 80, obs. J. Mestre et B. Fages. 


\section{0 excessivo (poderíamos ter ficado sem...)}

10 Nos termos do novo art. 1.117, a morte do destinatário da oferta acarreta a caducidade desta. Mustapha Mekki explicou suficientemente a inutilidade de uma tal regra para que nós nos detenhamos sobre esse assunto. ${ }^{12}$

Em suma, teríamos preferido que a lei de ratificação tivesse seguido o caminho trilhado pela Corte de Cassação em $2014^{13}$ e dispusesse que a oferta a determinada pessoa, em caso de demora na aceitação, sobreviveria à morte do ofertante. Regra amplamente justificada pela ideia de que, quando ele "formula sua proposta com um prazo definido de eficácia [...], essa decisão pode implicar em renúncia ao exercício do direito de revogar a oferta"; ${ }^{14}$ por conseguinte, mutatis mutandis, "quando o proponente renuncia à prerrogativa de revogar a oferta durante determinado período e falece antes da expiração de tal período, imagina-se que a oferta sobreviveria à sua morte". ${ }^{15}$

11 Além disso, era indispensável modificar a letra do art. 1.223, que prevê, a título de sanção da execução imperfeita, a redução do preço?

Certamente, alguns postularam nesse sentido e desejavam que a literalidade do texto não permitisse saber se ele instauraria um regime dual de redução do preço (redução judicial com a primeira alínea, redução unilateral com a segunda alínea) ou se a mera redução unilateral do preço poderia ser inferida do art. 1.223.

Argumentação discutível, para dizer o mínimo, nem que seja em relação à estrutura do texto. Se este último tivesse considerado tão somente uma redução unilateral do preço, ele teria sido efetivamente inútil ao estabelecer duas alíneas distintas para a sanção da execução imperfeita. Seria suficiente escrever que: "Em caso de execução imperfeita, o credor pode, após notificação formal, postular ao juiz a redução proporcional do preço" ou, ao contrário, que: "Em caso de execução imperfeita, o credor pode notificar o devedor acerca de sua decisão de reduzir o preço". Em suma, a existência de duas alíneas no art. 1.223 revela suficientemente a dualidade de regimes à qual esta sanção deve obedecer, conforme o preço tenha ou não sido pago. Portanto, uma reforma desse texto não se impunha de forma óbvia.

No entanto, a lei de ratificação altera o art. 1.223 e põe os pingos nos is. Doravante, se o credor ainda não houver pagado o preço, ele poderá "notificar o

12 Eod. IOC., ํํ 27.

13 Civ. 1re, 25/06/2014, no 13-16.529, D. 2014. 1574, note A. Tadros, 1715, chron. I. Darret-Courgeon et I. Guyon-Renard, et 2015. 529, obs. S. Amrani-Mekki et M. Mekki; AJ fam. 2014. 509, obs. C. Vernières; RTD civ. 2014. 877, obs. H. Barbier; RDC 2014. 601, obs. Y.-M. Laithier, et 2015. 53, obs. R. Libchaber.

14 F. Zenati-Castaing et T. Revet, Cours de droit civil, Contrats, Théorie générale-Quasi-contrats, PUF, 2014, spéc. no 90.

15 Ibid., spéc. no 91. 
mais rápido possível" o devedor de sua decisão de reduzir proporcionalmente o preço. E se o preço já tiver sido pago, "ele poderá postular ao juiz a redução do preço".

No primeiro caso, o novo texto esclarece que a "aceitação" pelo devedor dessa redução unilateral "deve ser redigida por escrito". Isso não significa, evidentemente, que a redução unilateral seja impossível por falta de aceitação do preço pelo devedor, mas que essa aceitação equivale a uma alteração convencional do contrato, que, como tal, será irrevogável unilateralmente e que uma eventual recusa quanto ao princípio da redução ou à sua importância se traduzirá em uma ação na justiça. ${ }^{16}$ No segundo caso, o texto esclarece que a redução judicial é suscetível de intervir "na falta de acordo entre as partes". Evidência da qual o legislador poderia ter dispensado os juristas e os jurisdicionados...

\section{0 reconfortante (para os admiradores do modelo contratual tradicional francês)}

12 Nos termos do art. 1.221, tal qual objeto do decreto-lei: "O credor de uma obrigação pode, mediante notificação formal, perseguir o cumprimento da prestação, salvo se tal cumprimento for impossível ou se existir uma desproporção manifesta entre o seu custo para o devedor e o seu interesse para o credor".

Essa nova exceção ao princípio da execução específica suscitou uma controvérsia quanto ao seu impacto sobre o nosso modelo contratual. Alguns a culparam por ter acarretado uma violação fatal ao princípio do respeito à palavra dada, segundo o qual a palavra contratualmente dada tem um valor tão significativo que ela não tem preço (compreendendo-se, por aí, que ela não pode ser compensada pelo devedor por meio do pagamento de perdas e danos para se eximir da prestação), em nome do imperativo de eficácia econômica do direito. Outros responderam que ela era apenas uma expressão da tradicional vedação do abuso, que transcende o nosso direito privado e que canaliza o exercício de todos os direitos, poderes e prerrogativas.

O que quer que tenha sido, a lei de ratificação limita, de agora em diante, o alcance dessa exceção de ordem econômica, eis que apenas o devedor de boa-fé poderá opô-la ao credor. Os amantes da ética irão aderir a essa retomada da força da moral contratual na aplicação da regra, já que, doravante, no fundo, o abuso do credor será neutralizado pela má-fé do devedor.

16 F. Zenati-Castaing et T. Revet, Cours de droit civil, Contrats, Théorie générale-Quasi-contrats, PUF, 2018, spéc. $\mathrm{n}$ 은 221 . 
Resta, então, identificar os contornos da má-fé que deverá ser provada pelo credor, ao pretender obter a execução específica da prestação a despeito da desproporção manifesta entre o interesse que ela representa para ele e o custo que ela representa para o devedor. Em um primeiro momento, pode-se pensar na hipótese na qual o devedor será declarado culpado por uma conduta dolosa durante a execução do contrato, caracterizada quer pela intenção de prejudicar, quer por uma inexecução deliberada. Em um segundo momento, tal como sugerem de forma pertinente os Srs. Zenati-Castaing e Revet, a má-fé do devedor parece restar afastada quando "a desproporção entre o custo da execução in natura e a vantagem for constatada após a celebração do contrato, sem que o devedor possa tê-la legitimamente previsto". ${ }^{17}$

Em última análise, o destino do princípio do respeito à palavra dada, representativo do modelo contratual francês, e o alcance da exceção de ordem econômica, que tempera a força desse princípio, dependerão, mais uma vez, da forma como os juízes, mais do que nunca coautores da reforma, explorarão esse standard que constitui a boa-fé, a qual sabemos que o decreto-lei preconizou, ainda que virtualmente, ao lado da liberdade e da segurança contratual, no estatuto de princípios diretores do nosso novo direito.

\section{0 menos bom...}

13 Uma análise objetiva do decreto-lei conduziria à constatação de que ela mantivera uma ilha de justiça contratual no âmbito de um oceano liberal. Por meio de duas de suas disposições, a lei de ratificação submerge a referida ilha, o que podemos lamentar, já que assim se fez romper o frágil equilíbrio trazido pelo decreto-lei.

$14 \mathrm{Em}$ primeiro lugar, a lei de ratificação regulamenta a questão da influência de um erro sobre o valor, provocada por uma reticência dolosa, sobre o destino do contrato.

Os dispositivos do decreto-lei, devido à sua delicada conciliação, dividiam a doutrina acerca da resposta a ser dada a essa questão.

Alguns autores, apaixonados pela segurança jurídica e preocupados em assegurar uma continuidade com o direito anterior, ${ }^{18}$ apoiavam-se no art. 1.112-1,

Ibid., spéc. ํo 216 .

18 Civ. 1re, 03/05/2000, no 98-11.381, D. 2002. 928, obs. O. Tournafond; RTD civ. 2000. 566, obs. J. Mestre et B. Fages; CCC 2000. Comm. 140, obs. L. Leveneur; Defrénois 2000, obs. P. Delebecque et D. Mazeaud; JCP 2000. II. 10510, obs. C. Jamin; 17/01/2007, no 06-10.442, D. 2007. 1051, note D. Mazeaud, 1054, note P. Stoffel-Munck, et 2966, obs. B. Fauvarque- Cosson; AJDI 2007. 416, obs. S. 
alínea 2, que exclui toda obrigação de informação sobre o valor da prestação, e defendiam ser inócuo o silêncio de um contratante quando este provocasse tão somente um erro sobre o valor. ${ }^{19}$ Segundo eles, a existência de uma reticência dolosa pressupõe, como prerrequisito, a existência de uma obrigação de informação; apesar disso, esta é afastada, pelo dispositivo anteriormente citado, quanto ao valor da prestação; logicamente, então, o silêncio sobre o valor não caracteriza uma reticência dolosa, não levando, pois, à nulidade do contrato.

Outros autores, mais preocupados com a ética contratual, fundam-se notadamente na literalidade do art. 1.137, alínea 2, e sustentam que o decreto-lei havia efetuado uma "desvinculação" 20 entre a obrigação de informação e a reticência dolosa. Desvinculação que procedia da definição da reticência dolosa estabelecida pelo art. 1.137, alínea 2, cujo centro de gravidade é evidentemente a má-fé da qual estava imbuído o seu autor. Por conseguinte, pouco importa o objeto do seu silêncio desleal e do erro que ele provoca. Além disso, o art. 1.139 dispunha expressamente que o erro sobre o valor decorrente de dolo deve acarretar a nulidade do contrato. Contudo, a reticência dolosa é justamente uma forma de dolo... De igual modo, por menos ligados que sejamos às ideias de que o contrato deve assentar na justiça e de que o direito que o rege não pode ferir o sentimento elementar de ética contratual, poderíamos legitimamente endossar, com louvor, a premissa de que o silêncio intencional sobre uma informação determinante do consentimento de um contratante constitui uma reticência dolosa que deve acarretar a nulidade do contrato. E não seria ilegítimo pensar que os juízes, apesar da jurisprudência anterior e em razão da literalidade dos arts. 1.137, alínea 2, e 1.139, adotarão essa solução.

A lei de ratificação, todavia, escamoteia definitivamente essas esperanças. o art. 1.137, alínea 2, dispõe doravante que não configura dolo o fato de se manter silêncio sobre a estimativa de valor da prestação. Logo, um contratante que negocia de má-fé e se cala intencionalmente sobre esse ponto, sabendo que o seu silêncio provocará um erro determinante no consentimento do seu cocontratante, não tem nada a temer quanto à validade do contrato que ele celebra

Bigot De La Touanne; RTD civ. 2007. 335, obs. J. Mestre et B. Fages; CCC 2007. Comm. 117, obs. L. Leveneur; Defrénois 2007. 443, obs. E. Savaux; JCP 2007. II. 10042, obs. C. Jamin; RDC 2007. 703, obs. Y.-M. Laithier.

19 F. Dourmaux, La réforme des vices du consentement, Dr. et patr. 2016, nํ2 258, p. 57 s., spéc. p. 59 ; B. Fages, Droit des obligations, LGDJ, 2016, spéc. № 115.

20 O. Deshayes, La formation des contrats, RDC 2016. 21 s., spéc. 26. V. aussi, G. Chantepie et M. Latina, La réforme du droit des obligations, Dalloz, 2016, spéc. no 327; O. Deshayes, T. Genicon et Y.-M. Laithier, Réforme du droit des contrats, du régime général et de la preuve des obligations, LexisNexis, 2016, spéc. p. 204; N. Dissaux et C. Jamin, Réforme du droit des contrats, du régime général et de la preuve des obligations, Dalloz, 2016, spéc. p. 43. 
de forma desleal. Para bom entendedor, meia palavra basta! Passemos ao fato de que 0 art. 1.139, objeto do decreto-lei, que enuncia que o erro sobre o valor provocado por dolo acarreta a nulidade do contrato, está mantido incólume. A reticência dolosa não é mais, portanto, um dolo como os outros. Que progresso! Eis que voltamos atrás mais de meio século. Mas a atratividade do direito francês vale, sem dúvidas, algumas atenções à boa-fé e à coerência mais elementar possível. É verdadeiramente necessário não querer colaborar para se queixar de um dispositivo graças ao qual os operadores internacionais certamente irão sucumbir, enfim, ao charme do direito contratual francês...

$15 \mathrm{E}$ é esse mesmo sentimento que inspira a reforma do art. 1.143, que, no decreto-lei, enunciava:

Há coação igualmente quando uma parte, abusando do estado de dependência em que se encontra o seu cocontratante, obtém deste uma vantagem manifestamente excessiva, por meio de uma contratação com a qual ele não teria se comprometido na ausência de tamanho constrangimento.

O impacto dessa regra sobre o nosso modelo contratual era considerável, uma vez que acarretava o temperamento do princípio da validade, da eficácia e da intangibilidade dos contratos leoninos. De fato, uma vez afetado por um desequilíbrio manifestamente excessivo, engendrado pela exploração abusiva de um estado de dependência, o contrato era anulado. 0 que equivale a dizer que esse dispositivo permitia ao juiz que se imiscuísse no contrato para corrigir as injustiças contratuais mais flagrantes.

Ao temperar uma regra emblemática do nosso modelo contratual tradicional, esse novo vício do consentimento, que se revestia, de fato, de um vício contratual, tinha sido criticado, e a tentação de lhe reduzir o alcance era forte para os apóstolos do liberalismo, os quais haviam sugerido restringi-lo ao único caso no qual o estado de dependência fosse de ordem econômica.

A lei de ratificação os ouviu, mas estabeleceu um outro limite à exploração desse vício, porquanto o art. 1.143 dispõe, de agora em diante, que a sua ocorrência só restará caracterizada se uma parte abusar "do estado de dependência no qual se encontra a contraparte em relação àquela primeira [...]".

Um pouco mais de segurança jurídica e sempre menos justiça contratual, portanto! Resta determinar o sentido desses termos. É certo que esse novo vício de coação não poderá emanar de um terceiro ao contrato, mesmo que seja cúmplice do contratante que abusa do estado de dependência de seu cocontratante. 0 abuso de dependência não é, pois, uma violência pré-contratual como as outras. 
Muito bom ou, em vez disso, muito ruim! É também possível que o vício seja afastado quando a dependência tiver sido fruto não de um comportamento censurável do contratante (que tirará vantagem manifestamente excessiva de sua contraparte dependente), mas sim de fatores inerentes a esta.

Não é necessário ser um grande profissional do direito para se antever que o âmbito de aplicação desse novo vício, que introduzia uma dose bem-vinda de justiça contratual no nosso modelo contratual, corre o risco de ser substancialmente limitado, para o bem maior da atratividade do nosso novo direito. Esse "retrocesso" é, como assinalaram precisamente os Srs. Zenati-Castaing e Revet, “lamentável". ${ }^{21}$ É o mínimo que se pode dizer.

\section{0 melhor}

16 Quando for o tempo de darmos um passo atrás e nos questionarmos acerca da influência da doutrina sobre a reforma do direito dos contratos, o nome do meu amigo Thierry Revet ocupará um lugar primordial. A luta feroz que ele travou e ganhou com relação à definição do contrato de adesão restará inevitavelmente gravada em nossas memórias. E o seu empenho terá sido tanto mais importante que incidirá sobre a verdadeira revolução da reforma, qual seja, a intromissão do contrato de adesão no Código Civil.

Intromissão essa que chancela a ideia proposta por Zenati-Castaing e Revet, segundo os quais o nosso universo contratual é composto por dois planetas distintos. O primeiro compreende os contratos estruturalmente equilibrados, isto é, aqueles negociados de forma livre e efetiva. 0 segundo abrange os contratos estruturalmente desequilibrados, que, devido à relação de forças que preside a sua celebração, não são livremente negociados. E essa profunda diferença entre a natureza de ambos, que, com a reforma, também se irradia sobre os contratos abrangidos pelo campo de aplicação do Código Civil, implica fatalmente uma distinção de regimes. ${ }^{22}$ Mais ainda, essa intromissão leva a reconhecer que, mesmo no direito comum dos contratos, vontade e contrato não mais rimam necessariamente:

o decreto-lei de 10/02/2016 leva em consideração que a vontade das partes não constitui mais o alpha e o ômega ${ }^{23}$ do contrato; 0 momento no qual uma vontade aceita o conteúdo de um ato jurídico que ela não havia nem elaborado nem podido discutir, tal ato pode

21 Ibid., spéc. ํㅜ 85.

22 Ibid., passim.

23 É o autor que sublinha. 
obter o título de contrato, da mesma forma como nos casos em que a vontade das duas partes lhe houver determinado o conteúdo. ${ }^{24}$

Sozinho contra todos, ou praticamente, Thierry Revet, com ideologia claramente assumida, lutou para que a noção de contrato de adesão fosse amplamente apreendida. Primeiro, ao neutralizar o obstáculo das condições gerais que o decreto-lei havia explorado para canalizar a qualificação do contrato de adesão, ao reservá-la apenas às hipóteses nas quais a determinação unilateral do conteúdo do contrato tiver essas cláusulas por objeto. Enquanto alguns propunham identificar essas condições gerais, raciocinando nos termos do direito comum e opondo-as às condições particulares, o novo corsário do direito dos contratos se opunha a tal proposição, fundamentando-se na "ratio legis da recepção, pelo direito comum, do contrato de adesão", a qual reside "na vontade de distinguir os contratos cujo conteúdo pôde ser negociado e aqueles cujo conteúdo não o pôde ser" ${ }^{25}$ Nessa perspectiva, "a noção das condições gerais devia receber um sentido condizente com o contrato de adesão", entendendo-se "pelo conteúdo do contrato tomado em seu todo, porque o contrato de adesão é aquele cujo conteúdo não pôde ser negociado por um dos contratantes, o qual não teve outra possibilidade senão aceitar ou recusar em bloco o conteúdo proposto pelo outro" ${ }^{26} \mathrm{Em}$ suma, o que distingue o contrato mutuamente acordado e o contrato de adesão é a impossibilidade de negociar o conteúdo do contrato que caracteriza o segundo: é pegar ou largar! Aos contratos bilateralmente celebrados e concebidos, é preciso, pois, opor os contratos celebrados bilateralmente, mas concebidos unilateralmente. Os primeiros são mutuamente acordados; os segundos, de adesão. Quod erat demonstrandum!

E depois, em um artigo tão estimulante quanto enérgico, publicado nesta Coletânea, ele havia dito todo o mal que pensava do "incoerente acantonamento, pela Assembleia nacional, do domínio do contrato de adesão aos contratos massificados". ${ }^{27}$ A sua pena, molhada em uma tinta de renovada filosofia contratual, acertou a primeira, porque a lei de ratificação suprimiu essa inoportuna limitação.

De agora em diante, na verdade, o contrato de adesão é, em virtude do art. 1.110, alínea 2, "aquele que compreende um conjunto de cláusulas não negociáveis, determinadas de antemão por uma das partes". No fundo, o contrato de

L'incohérent cantonnement, par l'Assemblée nationale, du domaine du contrat d'adhésion aux contrats de masse, D. 2018. 124.

25 T. Revet, Les critères du contrat d'adhésion. Article 1110 nouveau du code civil, D. 2016. 1771, spéc. nํㄱ.

26 Ibid., spéc. no 8.

27 D. 2018.124. 
adesão é, pois, aquele cujo "conjunto de cláusulas" é definido unilateralmente por um dos contratantes e imposto ao outro, o qual é desprovido de todo e qualquer poder de negociá-las.

A dificuldade, mas não a única, consiste em identificar o conceito de "conjunto de cláusulas não negociáveis". Primeiro, é certo que não é necessário que todas as cláusulas do contrato não sejam negociáveis para que este seja qualificado como contrato de adesão. Em seguida, é concebível reservar um critério quantitativo e decidir que o contrato é de adesão quando comportar um grande número de cláusulas insuscetíveis de negociação. ${ }^{28}$ Enfim, e é este o critério que nos parece mais pertinente, é com relação à importância das cláusulas não negociáveis em relação ao equilíbrio contratual que poderia se operar a qualificação. ${ }^{29}$ Interpretação que, por outro lado, "merece" estar em sintonia com a principal consequência prática da qualificação do contrato de adesão, qual seja, a proteção do aderente contra as cláusulas abusivas.

Última dificuldade, mas não menos importante, é determinar sobre qual dos contratantes deve recair o ônus da prova da não negociabilidade. Seria oportuno que, quando o contratante do aderente alegar que um conjunto de cláusulas era negociável, a prova dessa negociabilidade recaísse sobre ele.

17 Consequência da intromissão do contrato de adesão no Código Civil, este comporta, de agora em diante, como o código do consumidor (art. L. 212-1, alínea 1) e o Código Comercial (art. L. 442-6, I, 2º), uma regra de proteção contra as cláusulas abusivas. 0 art. 1.171 do código civil, tal como emanado da lei de ratificação, permite ao juiz que repute não escritas as cláusulas não negociáveis determinadas previamente por um dos contratantes, caso tenham sido estipuladas em um contrato de adesão e criem um desequilíbrio contratual significativo.

Uma cláusula que acarreta um desequilíbrio significativo só pode ser reputada abusiva, portanto, se tiver sido estipulada em um contrato de adesão e se não tiver sido negociável. Certamente, o campo de aplicação da proteção é limitado àquilo que o decreto-lei havia editado, pois bastaria, para que ela fosse afastada do contrato, que uma cláusula tivesse sido inserida em um contrato de adesão, sem que fosse necessário indagar se, além disso, ela teria sido ou não negociável. Mas essa restrição é legítima se partirmos da premissa de que a proteção contra as cláusulas abusivas tem como razão de ser a impossibilidade de o aderente livremente negociar o conteúdo da cláusula controvertida: é legítimo, então, que ele não suporte os desequilíbrios excessivos que não sejam fruto da liberdade contratual, mas produto da liberdade unilateral do contratante que Ihe impusera.

Nesse sentido, V. F. Zenati-Castaing et T. Revet, op. cit., 2018, a publicar, spéc. no 8.

29 Ibid. 
Fossem as cláusulas negociáveis, até mesmo em um contrato de adesão, a proteção não se tornaria necessária, pois o contratante teria tido o poder de recusar a cláusula, de discutir o seu conteúdo.

Quanto à prova da não negociabilidade, recordaremos que o art. 33 da proposta de diretiva do Parlamento e do Conselho relativo aos direitos dos consumidores de 8.10.2008 dispunha que: "Se o profissional alegar que uma cláusula contratual foi objeto de negociação individual, o ônus da prova Ihe incumbe". É uma pena que o legislador francês não tenha se inspirado nesse texto que reforça sensivelmente a proteção do aderente.

Já cacarejamos bastante sobre a legitimidade da regra enunciada pelo art. 1.171, ao menos em sua versão inicial, mas a sua nova versão não pacificará a controvérsia, uma vez que é o seu próprio princípio que é debatido. Devido à falta de nitidez em torno do conceito de "desequilíbrio significativo", esse texto foi acusado de constituir um fator de insegurança jurídica e de judicialização do contrato e, por consequência, de ser um espantalho que desviará os agentes econômicos do nosso direito. Nós conhecemos a canção...

O argumento relativo ao "desequilíbrio significativo" não é novo, ele já havia sido brandido à época da lei relativa à proteção dos profissionais contra as cláusulas abusivas. Precisamente, já tinha sido levada ao Conselho Constitucional uma questão prioritária de constitucionalidade $(Q P C)$ relativa à compatibilidade da emenda, prevista no Código Comercial para sancionar o profissional que impõe uma cláusula abusiva ao seu parceiro, com o art. 8o da Declaração dos Direitos do Homem e do Cidadão.

A fim de decidir que o artigo controvertido estava em consonância com o princípio da legalidade dos delitos e das penas, o Conselho considerou, em uma decisão de 13.1.2011, que a noção de desequilíbrio contratual significativo incriminado pelo art. L. 442-6, I, 2º, do Código Comercial era... suficientemente clara e precisa, considerando-se que a jurisprudência já havia tratado a questão com precisão na ocasião da proteção dos consumidores contra as cláusulas abusivas, com fundamento no art. L. 132-1 do Código de Consumo (então aplicável). 0 que equivale a dizer que a crítica tendo em conta a confusão da noção de desequilíbrio significativo, regularmente brandida por aqueles que criticam a política de proteção contra as cláusulas abusivas, é tão recorrente quanto ineficaz.

De qualquer maneira, essa proteção contra as cláusulas abusivas doravante organizada no seio do próprio Código Civil parece-nos perfeitamente legítima, e por várias razões.

Por um lado, para aqueles que criticam a existência de uma tal regra protetiva no Código Civil, nós responderemos que não compreendemos por que uma cláusula, estipulada nas mesmas condições e criando um desequilíbrio significativo, 
seria sancionada quando o contrato, no qual ela foi estipulada, entrar no âmbito de aplicação do Código de Consumo ou do Código Comercial, e não o seria se regida pelo Código Civil. Criar-se-ia, assim, uma discriminação entre os contratantes vítimas de cláusulas abusivas, cuja razão de ser não percebemos. As mesmas cláusulas devem produzir os mesmos efeitos!

Por outro lado, para aqueles que se comovem com os potenciais prejuízos causados por esse novo poder outorgado ao juiz de reputar não escritas as cláusulas abusivas, nós os tranquilizaremos lembrando que o seu campo de aplicação é rigorosamente circunscrito pelo texto. Não bastasse a dupla condição que a lei impõe, o poder do juiz é, além disso, neutralizado quando a cláusula recair sobre o objeto principal do contrato ou sobre a adequação do preço à prestação. De mais a mais, a regra do Código Civil (regra do direito comum) poderá ser eventualmente afastada, desde que as regras do direito especial (Código de Consumo e Código Comercial) se apliquem à hipótese, o que, muito provavelmente, restringirá de modo sensível o campo de aplicação daquela.

Então, a segurança jurídica não deverá ser muito afetada com a nova regra inserida no Código Civil e a justiça contratual poderá manter-se, sem invadir, contudo, o nosso novo modelo contratual. Está tudo certo no melhor dos mundos contratuais...

Informação bibliográfica deste texto, conforme a NBR 6023:2018 da Associação Brasileira de Normas Técnicas (ABNT):

MAZEAUD, Denis. Algumas considerações sobre a reforma do direito dos contratos. Tradução de Victor Willcox. Revista Brasileira de Direito Civil - RBDCivil, Belo Horizonte, v. 28, p. 175-189, abr./jun. 2021. 